DeVille / The Levantine Review Volume 2 Number 1 (Spring 2013)

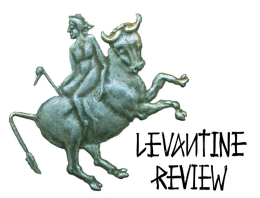

\title{
SOME METHODOLOGICAL CONSIDERATIONS FOR THE STUDY OF THE HISTORIC AND CURRENT ENCOUNTERS BETWEEN CHRISTIAN AND MUSLIM COMMUNITIES
}

\author{
Adam A.J. DeVille*
}

\begin{abstract}
Drawing on, but expanding and altering mutatis mutandis some principles enunciated by the greatest Byzantine liturgical historian writing today, Robert F. Taft (emeritus of the Pontifical Oriental Institute in Rome,) this paper will propose some methodological considerations for the study of the encounters and relations between Eastern Christian and Muslim communities from the seventh century to the present day. Such encounters are little studied even in a time of great focus on the Middle East and the so-called Arab Spring. Such encounters have so often been ignored or subject to partial, prejudicial, politicized, decontextualized, or otherwise tendentious treatment which, as often as not, obscures rather than illuminates, sometimes serving as a plaidoyer for Islam. As a consequence, the reality of life for millions of people over fourteen centuries-people such as Coptic Orthodox Christians in Egypt, Maronite Christians in Lebanon, Assyrian and Chaldean Christians in Iraq, Armenian Christians in Iran, and numerous others - remains virtually unknown today in academic, political, and even Christian circles in North America. As scholarship on these encounters emerges, it seems important to lay out ab initio some methodological considerations or guiding principles. This paper will propose a few such principles and then illustrate their importance by means of critically reviewing some recent scholarly articles and books on the Christian-Muslim encounter.
\end{abstract}

\section{INTRODUCTION}

This paper arises out of a half-decade of frustration with the state of scholarship on Eastern Christian and Muslim encounters. In 2007 I designed a new undergraduate course "Eastern Christianity and the Encounter with Islam" to teach each semester as a way of bringing attention to both traditions in a curriculum that until that point paid no attention to either. Then began the endlessly frustrating hunt for suitable texts. Very quickly it became obvious-once again - that Eastern Christianity lacks the same scholarly coverage that Western Christian communities-both Roman Catholic and Protestant-have enjoyed for centuries. Even more glaring is the gap in serious scholarship treating encounters between Muslims and Eastern Christians. 


\section{DeVille / The Levantine Review Volume 2 Number 1 (Spring 2013)}

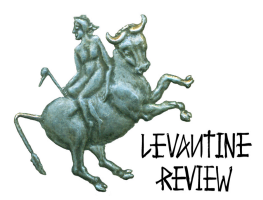

Thus those texts that do treat Christian-Muslim encounters often ignore Eastern Christian communities almost entirely. ${ }^{1}$ Of the books that do look at Eastern Christian-Muslim encounters, many were ruled out because they were badly written, ${ }^{2}$ out of date, ${ }^{3}$ incomprehensive, ${ }^{4}$ polemical ${ }^{5}$ or apologetical in tone, ${ }^{6}$ based

1 This is not surprising insofar as any serious academic study of Eastern Christianity by and in Western academic contexts is an extremely young discipline that only within the last two decades has begun to attract anything like the same critical attention from scholars and publishers that Western Christian traditions have enjoyed for centuries. Part of this stems from the fact that until 1991 the largest Eastern Christian communities in the world were behind the iron curtain of the USSR-and for centuries before that, of course, laboured under Islamic domination. Today, however, major presses are showing an ever greater interest in publishing books about Eastern Christian realities. I keep track of some of this massive outpouring of new publications as http://easternchristianbooks.blogspot.com, a blog associated with the academic revue, Logos: A Journal of Eastern Christian Studies, the oldest such journal of its kind in North America.

2 The most egregious example of this is the collection edited by Dietmar W. Winkler, Syriac Churches Encountering Islam: Past Experiences and Future Perspectives (Gorgias Press, 2010). As I noted in a long discussion of it, I have never before encountered such an appallingly unedited book filled with articles by nonanglophones (save for Sidney Griffith's excellent article), edited by a nonanglophone, with results for all to see: well over 200 errors mar nearly every page of this book, which is very unfortunate not only because of its steep price, but especially because serious scholarship on the Syriac Churches and Islam is a huge desideratum today. My review is here: http://easternchristianbooks.blogspot.com/2011/10/eastern-christianity-andislam-iv.html.

${ }^{3}$ N.M. Vaporis, Witnesses for Christ: Orthodox Christian Neomartyrs of the Ottoman Period, 1437-1860 (Crestwood, NY: St. Vladimir's Seminary Press, 2000). ${ }^{4}$ Habib C. Malik's little book, Islamism and the Future of the Christians of the Middle East (Hoover Institute Press, 2010) does a commendable job of talking about Eastern Christian-Muslim relations in Lebanon, but as I have argued elsewhere in some detail, he goes beyond his brief in trying to suggest that Christians in other parts of the world-he focuses on the Copts-should learn from the Lebanese example, which is far from easy to do. Indeed, his book is marred by a certain de haut en bas tone when it comes to discussing the Copts, to whom Malik offers counsel that I think is unhelpful. It is very easy to fight for an idealistic vision of freedom from the outside when you do not have to suffer the consequences; it is facile to recommend the path of martyrdom to others when there is no danger of your own head being hacked off and placed on Traitor's Gate pour encourager les 


\section{DeVille / The Levantine Review Volume 2 Number 1 (Spring 2013)}

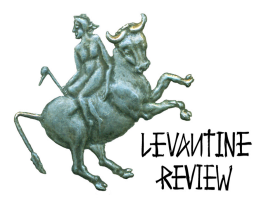

on inadequate (or no) scholarship, ${ }^{7}$ or otherwise maliciously stupid and ignorant tracts that should never have been published. ${ }^{8}$

autres. In any event, developments in Egypt since December 2012 have now made much if not all of Malik's counsel to the Copts irrelevant.

There are other books that, while good, focus on only one region. E.g., George C. Papademetriou, Two Traditions, One Space: Orthodox Christians and Muslims in Dialogue (Somerset Hall Press, 2010). The title is deceptive insofar as the book only focuses on one group of Orthodox Christians-the Greeks. I review the book here: http://easternchristianbooks.blogspot.com/2011/07/eastern-christianity-andislam-ii.html.

Russia is the one area that has so far garnered the most attention in this regard, with numerous recent publications of widely varying quality. Some of the better ones include Roland Dannreuther and Luke March, eds., Russia and Islam: State, Society and Radicalism (Routledge, 2011); Robert Crews, For Prophet and Tsar: Islam and Empire in Russia and Central Asia (Harvard UP, 2009); Galina Yemelianova, ed., Radical Islam in the Former Soviet Union (Routledge, 2011) and Idem, Russia and Islam: a Historical Survey (Palgrave Macmillan, 2002); Benjamin Forest et al, ed., Religion And Identity In Modern Russia: The Revival Of Orthodoxy And Islam (Ashgate, 2005).

5 The most famous example of this historically of course is the treatment by St. John of Damascus.

${ }^{6}$ E.g., Mark Durie, The Third Choice: Islam, Dhimmitude and Freedom (Deror Books, 2010). I reviewed this book in Reviews in Religion and Theology 18 (2011): 61-63. There I argued that Durie raises some very good points, but relies too heavily and uncritically on Bat Ye'or's work, about which see below.

7 While commendable in some respects, the book edited by Jack Figel, Byzantine Christianity and Islam: Historical and Pastoral Reflections (Eastern Christian Publications, 2001) is an omnium gatherum that does not attend to a great deal of scholarship but consists in significant measure of pastoral letters from Orthodox bishops about Islam and similar types of writings. The worst example I have seen of a book that ignores relevant scholarship is Ralph Sidway's more or less selfpublished book Facing Islam: What the Ancient Church Has to Say about the Religion of Muhammad, which is polemical, apologetical in tone (for Orthodoxy), and based on no serious scholarship whatsoever. It was not competently edited. My review is here: http://easternchristianbooks.blogspot.com/2011/09/eastern-christianityand-islam-iii.html.

8 The most stunning example of this is Graham E. Fuller's $A$ World Without Islam (Little, Brown \& Co., 2010). This is a book so riddled with the most elementary of factual errors that it was obviously never edited by the publisher, much less sent out to specialists for careful review; it is a tract so marred by such a transparently tendentious treatment of its topics as to destroy any shred of credibility the author 


\section{DeVille / The Levantine Review Volume 2 Number 1 (Spring 2013)}

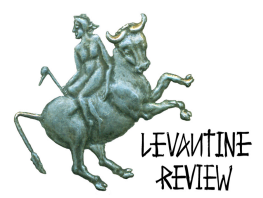

As I undertook my search for texts, I was acutely aware of the need for proceeding carefully and cautiously, not only because I firmly believe that is how any serious scholar must proceed, aware of his own limits and of what he does not know, but also because of the political minefields that are so rampant today when it comes to Islam in particular, or Middle Eastern and wider history in general. ${ }^{9}$ As Bernard Lewis has recently made clear in his winsome memoirs, quoting Anatole France, a good historian (or scholar in general) is one who enriches "his subject with a new uncertainty'."10 There is very much indeed to be uncertain about in trying to understand the encounters between Eastern Christians and Muslims, past and present, and this can never be forgotten. There are many serious and deep gaps in what we know, some of which will probably never be overcome. There are many complexities to the history of the encounters between Eastern Christians and Muslims that cannot be reductively simplified or ignored because of present felt purposes. This 1400-year history is not only long and complex, but it also touches, even today in some cases, on fundamental issues of life and death-quite literallyand so it cannot be treated with anything other than cautious respect for what we do not know.

Nevertheless, there are also some principles of which I was in fact quite sure in my search for books. In my search for suitable, usable texts, I had four:

- Accessibility: the texts had to be accessible to freshmen and sophomores with no background in either religion, and at best an extremely attenuated background in history and geography;

- Historical but Current: the ideal text would treat the first encounters, starting in Syria and Egypt, in the seventh century, and expand outwards both geographically and chronologically to include other encounters-the Caucasus, the Balkans, Slavic lands-from the seventh to the twenty-first centuries, being both historically informed about past encounters but also au courant with current relations;

- Comprehensive but Diverse: As just hinted at, I wanted a book that would not lump all Eastern Christians and all Muslims together and treat each as one

might once have had. It is, quite simply, the worst book I have ever read, for reasons I document in painful detail here: http://easternchristianbooks.blogspot.com/2010/12/nonsense-on-stilts.html.

${ }^{9}$ I was also aware that I am not trained as an Islamist or Orientalist: my areas of specialization include the structure of the Orthodox Churches and their relations, historic and current, with the Roman Catholic Church, especially the pope, which I treat in my first book Orthodoxy and the Roman Papacy (U Notre Dame Press, 2011). 10 Bernard Lewis, Notes on a Century: Reflections of a Middle East Historian (Viking, 2012), 142. 


\section{DeVille / The Levantine Review Volume 2 Number 1 (Spring 2013)}

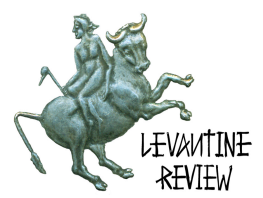

homogenous lump regardless of historical context. I took it as axiomatic that the encounter between Copts and Muslims in today's Egypt is not the same as it was there five centuries ago, and neither then nor today is that encounter the same as that between Armenians and Muslims or Russian Orthodox Christians and Muslims in, say, Tatarstan;

- Scholarly Reliability: The scholarship upon which any given text relied had to be free from anachronism, based on reliable sources, and free, so far as possible, from modern political tendentiousness. Thus polemics and apologias were ruled out. The stories of Eastern Christian-Muslim encounters had to be told simply, without an agenda, and without regard for whose ox got gored.

It was perhaps hopelessly naive of me to expect to find in any one text all four criteria adequately met. But what was even more frustrating was the fact that none of the books I examined met more than one of the above criteria. While there are many examples of excellent scholarly books, these were all inaccessible to the undergraduates I teach. ${ }^{11}$ Already drawing from a very small pool of possibilities (made even more restrictive, of course, by the fact that none of my students speaks or reads anything but English), I quickly saw that there would be no ideal text, but only a few barely adequate ones. ${ }^{12}$ I was left with two choices: to somehow use texts

${ }^{11}$ I do not want it understood that there are no good books out there-indeed there are numerous serious scholarly treatments of Eastern Christian-Muslim encounters, but none that would meet all four criteria for use in an undergraduate course-or, for that matter, for informing the general reader. Examples of solid, important scholarly work being done today would have to include-as I have argued elsewhere-Sidney Griffith's The Church in the Shadow of the Mosque: Christians and Muslims in the World of Islam (Princeton UP, 2007) (I discuss Griffith's book in Logos: A Journal of Eastern Christian Studies 49 [2008]: 340-42). Other solid scholarly treatments include Emmanouela Grypeou, Mark Swanson, David Thomas, eds., The Encounter of Eastern Christianity With Early Islam (Brill, 2006), but this book is far beyond undergraduates today. Many other examples could be mentioned-several volumes written or edited again by David Thomas, or the series on the Coptic papacy in which Swanson has played a part. Many good books continue to come put particularly from Brill, including their multivolume ChristianMuslim Relations: A Bibliographical History.

12 The text I settled on eventually and was using somewhat diffidently until recently was Anthony O'Mahony and Emma Loosley, eds., Christian Responses to Islam: Muslim-Christian Relations in the Modern World (U Manchester Press, 2008). This has decent chapters on Syria, Egypt, Iran, and Russia, though the Russia chapter is very weak in its sources, and the chapters on Syria and Egypt have now, of course, been surpassed by events on the ground from 2011 onward. This is a good text, but 


\section{DeVille / The Levantine Review Volume 2 Number 1 (Spring 2013)}

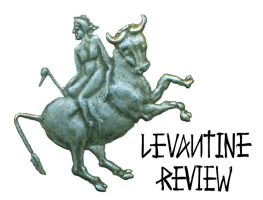

that were often outdated, written in a style that was inaccessible, heavily biased because of current political agendas, very limited in scope-treating only one country, or one historical period-or all of the above; or to put together something of my own. ${ }^{13}$

This latter prospect filled me with dread and so I kept putting it off. Now, however, it seems clear that such a text is more needed than ever, not least in the aftermath of the so-called Arab Spring, where the plight of such as the Copts in Egypt and the Melkite Greek Catholics and Orthodox in Syria (or Assyrians and others in Iraq) is both controverted and so very difficult - to put it mildly. Today, at long last, the plight of Eastern Christians in the Middle East and elsewhere is finally receiving some overdue attention not only from scholars, but especially in the popular media and even in discussions among policy-makers. As those encounters continue to be studied, it seems clear to me that there are several important principles that should guide that scholarship. What ought we to expect of scholars treating these varied encounters? What pitfalls should be avoided?

In a 1996 article, Robert F. Taft, a Jesuit widely recognized as the leading scholar today on Byzantine liturgical history, proposed a series of principles to govern what he called "ecumenical scholarship." 14 By "ecumenical," Taft was referring particularly to relations between the Catholic and Orthodox Churches, which, since 1965 , have gradually been overcoming their millennium-long estrangement and division and working towards rapprochement in a variety of ways. ${ }^{15}$ Taft's principles, I think, can be applied mutatis mutandis to an issue not of "ecumenical" scholarship but of inter-religious scholarship, ${ }^{16}$ viz., relations, both historic and

limited insofar as it only covers a few Eastern Christian communities, and tends to be very skimpy on history.

13 I have started doing precisely that, with a book under contract, "Eastern Christian Encounters with Islam," with Routledge Press and a hoped-for publication date of late 2014. One way to read this paper, then, is as a programmatic overview of what I hope my own volume will accomplish and the principles that will undergird it. 14 "Ecumenical Scholarship and the Catholic-Orthodox Epiclesis Dispute," Ostkirchlische Studien 45 (1996): 201-226.

15 Indeed, most scholars now believe that there is only one outstanding issue between them, and that is the question of the role and responsibilities of the pope of Rome, on which see my Orthodoxy and the Roman Papacy: Ut Unum Sint and the Prospects of East-West Unity (University of Notre Dame Press, 2011). 16 According to conventional usage, "ecumenical" (and its cognates) refers to relations between, and the search for the unity of, various Christian traditions. "Inter-religious" refers to relations between different religious groups-between Jews and Muslims in Israel, say, or Hindus and Sikhs in India, etc. 


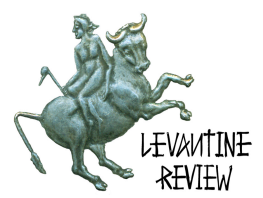

current, between Eastern Christians ${ }^{17}$ and Muslims around the world, but primarily in the Middle East, the Balkans, the Caucasus, and the territories of the former Soviet Union. I will draw on, and in some cases alter or considerably expand, Taft's principles and then illustrate their importance by review of several recent publications. My goal here is to move forward the scholarly discussion about Eastern Christian-Muslim encounters, a discussion that has in some commendable cases been done very well, but in far more cases has often been ignored, partial, onesided, or distorted for present political purposes.

\section{METHODOLOGICAL PRINCIPLES TO BE OBSERVED}

a) Principles of Scholarship in General:

Taft begins by laying out a series of principles governing his approach; an approach, which must govern all historical scholarship properly so called in any serious discipline by any reliable and responsible practitioner. ${ }^{18}$ In this regard Taft's approach bears striking similarities to two other leading historians of our time: to the Anglo-Canadian Margaret MacMillan, ${ }^{19}$ and most notably for our purposes here to Bernard Lewis, whose recent book Notes on a Century: Reflections of a Middle East Historian ${ }^{20}$ contains important methodological reflections very much in line with Taft's.

i) Primacy of Historical Fact and Context: First, he says, all scholarship is false (what he calls "pseudo-scholarship") "unless it is historico-critical, objective, fair, and representatively comprehensive." Simply put, you must, so far as it is clear and

\footnotetext{
17 "Eastern Christian" is the broader and more inclusive and hence preferable nomenclature to describe four main groups: Eastern or Byzantine Orthodox Christians, Oriental or non-Chalcedonian Orthodox, the Assyrian Church of the East, and the Oriental Catholic Churches. The best introduction to this admittedly often bewildering world remains Ron Roberson, The Eastern Churches: A Brief Survey, $7^{\text {th }}$ ed. (Rome: Pontifical Oriental Institute, 2010). For data on Eastern Christians in the United States, see Alexis Krindatch, Atlas of American Orthodox Christian Churches (Holy Cross Press, 2011).

18 Taft is himself certainly the most widely respected Byzantine liturgical historian alive today, recipient of numerous awards and distinctions, including notably being inducted into the British Academy as a Corresponding Fellow, the highest honor the Academy confers on non-British academics in recognition of scholarly distinction. ${ }^{19}$ MacMillan's most recent book is Dangerous Games: The Uses and Abuses of History (Modern Library, 2010). Previously she wrote the much-lauded and fascinating study Paris 1919, about the peace conference that ended World War I and laid the groundwork for World War II.

${ }^{20}$ (Viking, 2012).
} 


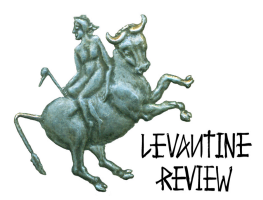

possible, "tell the truth, the whole truth and nothing but the truth." 21 By historicocritical Taft says that "one deals with texts and facts in context, ${ }^{22}$ and that theories cede to historical data, not vice-versa." By objective, he insists that "evidence must be presented not tendentiously slanted to support a position, but without bias." By comprehensive he says that while "no study can ever pretend to cover all the evidence," it is crucial that "the selection and presentation of the evidence must be [...] sufficiently representative to avoid glossing over or explaining away whatever does not fit comfortably into some preconceived theory." 23

ii) Fairness: ${ }^{24}$ In addition, Taft says, "one must be scrupulously fair in presenting and evaluating the evidence, sedulously avoiding caricature, and without substituting rhetoric for the facts." In other words, as Taft continues, "the true scholar seeks to find and present the truth wherever it is found, regardless of whom it pleases or displeases, or whose pet theories it confirms or contradicts." If it is undertaken in this way, such scholarship is "the opposite of confessional propaganda, which marshals evidence to support a predetermined doctrine."25

\section{b) Ecumenical Scholarship:}

Having thus stipulated general principles that Taft sees as binding on all historians, he then moves into the more specialized realm of history between Western and Eastern Christians, that is, between Catholics and Orthodox. This realm must be governed by the principles of "ecumenical scholarship." This kind of scholarship should not, Taft says, be content with only the foregoing principles. It needs to take "things a long step further." It needs five further principles governing it.

\footnotetext{
21 Bernard Lewis, Notes on a Century, 140.

22 Lewis also stresses that "context is critical": Ibid., 150.

23 This is part of the problem-as Sidney Griffith and others have argued-with Bat Ye'or's otherwise important work The Decline of Eastern Christianity Under Islam: From Jihad to Dhimmitude (Fairleigh Dickinson, 1996). In addition to being rather badly edited, it has a tendency to shoe-horn an undigested mass of data from many centuries and diverse historical contexts into a few theories about dhimmitude. See Griffith's review of Ye'or's book in International Journal of Middle East Studies 30 (1998): 619-21. See also Griffith's critical but appreciative comment on Ye'or's work in the former's The Church in the Shadow of the Mosque, 148, fn.61.

${ }^{24}$ Bernard Lewis also stresses "the importance of fairness" as part of a serious historian's methods: "if you wish to refute an argument, you must take as your target a fair statement of the best case possible for the point of view that you are trying to refute": Notes on a Century, 141.

${ }^{25}$ Lewis also notes that one must not indulge in "propaganda" and one must always "follow the evidence where it leads": Ibid., 145.
} 


\section{DeVille / The Levantine Review Volume 2 Number 1 (Spring 2013)}

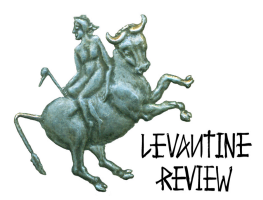

iii) No libido dominandi: The first pertains to the purpose of such scholarship, which should consist of "studying Christian tradition in order to reconcile and unite, rather than to confute and dominate." This approach to history, in other words, is not one that seeks to "win" over its ostensible opponents by showing them to be in error. There is no triumphalism or sanctimony here.

iv) Complementary, Not Contradictory: In studying differences between Eastern and Western Christians, the "deliberate intention is to emphasize the common tradition underlying differences, which, though real, can be the accidental product of history, culture, language, rather than essential differences in the doctrine of the faith."

v) No Romanticism: Taft says that while one must look for complementary understandings wherever possible, one must also be "scholarly" and this means one cannot "in any way gloss...over real differences." Recognizing differences, however, must be done in a way that judges each side and "its tradition by the exact same criteria and standards with which it judges the other."

vi) No Double-Standards or Scapegoats: Taft insists that scholarship must avoid "all scapegoating and the double-standard." In other words, as I have heard him describe it elsewhere, one must never indulge in the "my hands are always cleaner than yours" approach to history. ${ }^{26}$ Good scholarship must always seek "to describe the beliefs, traditions, and usages of other confessions in ways their own objective spokespersons would recognize as reliable and fair."27

vii) No Grotesques: Good scholarship must renounce "all caricature" and must not, covertly or overtly, subject the other tradition to criticism based on some "notion of contest or debate, seeking not confrontation but agreement and understanding."

viii) "Scholastic" Sympathy: Taft finally describes something that could be seen as "scholastic," specifically Thomistic in method: taking the arguments of "the other" so seriously and describing them with such sympathy, that the other would recognize what you say to be fair, accurate, and true. As Taft puts it, this approach "seeks to enter into the other's point of view, to understand it insofar as possible with sympathy and agreement." But it goes beyond that to take "seriously the

\footnotetext{
${ }^{26}$ He used this phrase when we were on a panel together at the Orientale Lumen Conference in Washington, DC in June 2011.

${ }^{27}$ Lewis makes a similar point, I think, in insisting that "one must guard against the danger of cultural arrogance" and try so far as possible to remain self-critical and impartial: Notes on a Century, 147.
} 


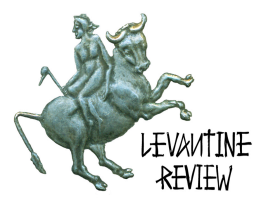

other's critique of one's own tradition, seeking to incorporate its positive contributions into one's own thinking."

\section{SCHOLARSHIP TREATING ISLAM}

To these eight important principles, I would add the following:

ix) Theology Cannot Be Ignored: I know that some historians, and some religious studies scholars, look upon theology with barely disguised horror and disdain, viewing it as no more respectable a discipline than phrenology or astrology. But the fact of the matter is that billions of Christian and Muslim believers subscribe to basic theological tenets that any scholar who wishes to be taken seriously must make an effort to understand and describe using the above principles, that is, fairly, objectively, and contextually. ${ }^{28}$ Vast sections of Islamic and Christian history as well as current practice will simply be incomprehensible without attending seriously and sympathetically to the theological foundations on which they rest. One does not, of course, need to accept as true any of these foundations, but to ignore them entirely, or to treat them through a reductionistic and simplistic lens of superstition and trickery, or an opioid to dull the pain of economic deprivation and social backwardness, is to render forever inaccessible the behaviour and beliefs of billions of one's fellow human beings.

x) The Quran Is Not the Same as the Bible: Again some, ${ }^{29}$ whether though academic snobbery and fear of contamination, or for whatever motive, tend to assume that all sacred texts are the same-a variation of the golden rule written by backwards windbags who threw in a lot of metaphysical nonsense alongside some supposedly shared or universal ethical principles. ${ }^{30}$ Though increasingly scholars ${ }^{31}$ are coming to see how much the Quran depends on the Bible, the New Testament in particular, it is nonetheless true that both books are very different not only in superficial ways-language and length-but above all in the claims they advance. To

28 One recent attempt to understand the theology of both Islam and Christianity is John Renard, Islam and Christianity: Theological Themes in Comparative Perspective (University of California Press, 2011).

${ }^{29}$ E.g., the many-and unreliable-books of someone like Karen Armstrong.

30 One happy exception to this is Stephen Prothero's book God is Not One: the Eight Rival Religions that Run the World (HarperOne, 2011). He commendably refuses to see all religions as basically teaching the same thing, and honestly recognizes that some make truth-claims that are irreconcilable to the truth-claims of all other religions. A clear example of this would be religious imagery: Eastern Christians have, since at least the eighth century, vigorously defended the use of icons while Islam in the main has been and remains deeply iconoclastic. 31 Sidney Griffith is the premiere example of such scholars. 


\section{DeVille / The Levantine Review Volume 2 Number 1 (Spring 2013)}

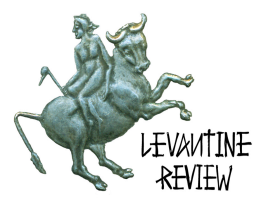

pick perhaps the two most obvious examples: the treatment of Jesus Christ in the New Testament is radically at odds with that in the Quran in several crucial respects, and the two texts and traditions plainly differ sharply on what monotheism is, the Quran rejecting any idea of a Trinity while the New Testament inchoately contains just such a theology properly so called. ${ }^{32}$ Thus any treatment of both books must not ignore differences even as it must not exaggerate either those differences or the real similarities. ${ }^{33}$

xi) The Crusades Must Be Properly Understood: It is very hard to avoid despair when it comes to discussion of the Crusades, especially at the "popular" level. Time and again the standard journalistic treatment is tedious, tiresome, and demonstrably false. ${ }^{34}$ If there is a topic more consistently, deliberately, grossly misunderstood and misrepresented, I am not sure what it is. Time and again the representation of the Crusades is monochromatic and one-dimensional: those bad, bloodthirsty colonial Christians from the imperious West went rampaging Eastward, in the process slaughtering Greek Christians, Jews, and of course Muslims, all of whom were as innocent and pure as the driven snow, and none of whom had done anything at all to provoke such attacks. Days after 9/11 Bill Clinton offered up just this sort of explanation as part of the search in those bewildering days for the "root causes" of the terrorist attacks. This is the widely accepted notion of the Crusades, even by many Christians. But to anyone who has even a passing acquaintance with the history, this is about as pure a species of what Taft denounces as "confessional propaganda" as you are likely to find. ${ }^{35}$ It grossly distorts not only the Christian

32 The Trinitarian theology of the New Testament would not be fully worked out for centuries, as Khaled Anatolios's recent and excellent book makes clear: Retrieving Nicaea: the Development and Meaning of Trinitarian Doctrine (Baker Academic, 2011).

${ }^{33}$ Good treatments here include Gabriel Said Reynolds, The Quran and its Biblical Subtext (Routledge, 2010). More generally, see James Cutsinger, Paths to the Heart: Sufism and the Christian East (World Wisdom, 2003).

${ }^{34}$ Reading such wearisome recyclage, I am put in mind of Conrad Black's acerbic description of most journalists as "ignorant, lazy, opinionated, and intellectually dishonest. The profession is heavily cluttered with aged hacks toiling through a miasma of mounting decrepitude and...arrogant and abrasive youngsters who substitute 'commitment' for insight. The product of their impassioned intervention in public affairs is more often confusion than lucidity."

35 Today we are slowly starting to break down some of this propaganda about the Crusades thanks to the work especially of Cambridge's Jonathan Riley-Smith in his many books. A good place to start might perhaps be his short article "Rethinking the Crusades," First Things (March 2000): http://www.firstthings.com/article/2007/ 01/rethinking-the-crusades-35. From there, see, inter alia, his books The Crusades, 


\section{DeVille / The Levantine Review Volume 2 Number 1 (Spring 2013)}

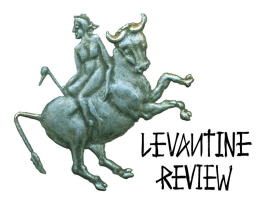

side, but also the Muslim ${ }^{36}$ and Jewish roles, reactions, and perceptions, then and since. It fails to consider different types of crusades in different periods (the Fourth, e.g., was vastly different from the previous three) and different motives. It is highly anachronistic in its understanding of when violence can be justified theologically.

xii) "Balance" Distorts: It is often said by and about journalists and other writers that they must be "balanced." Thus for every critical thing said about, e.g., Islam in India, an equal number of criticisms about Hindus there must also be offered if an essay or article is to be "balanced" and thus, ostensibly, "fair." But such a principle should, if anything, be observed only if the sources and evidence permit one to do so. Otherwise it is an ideological construct, a fetish even, that distorts more than anything. The most egregious recent examples of this include mainline media coverage-the BBC and New York Times in particular-of attacks on Coptic Christians in Alexandria on New Years Eve 2010. British and American media went out of their way to make it seem that this was the result of some long-standing feud between two equally matched, equally violent groups ("sectarian clashes" was the oft-heard phrase) in an endless battle of tit-for-tat in which it was impossible to say who was victim and who the aggressor. It was, of course, no such thing: it was an unprovoked attack on innocent churchgoers for no other reason than their being Christian. Any attempt to portray the Copts as being as prone to violence as Muslims in Egypt is demonstrably false.

Christianity, and Islam (Columbia University Press, 2008); The Crusades: A History (Yale UP, 2005); The Oxford History of the Crusades (OUP, 2002); What Were the Crusades, $4^{\text {th }}$ ed. (San Francisco: Ignatius Press, 2009); The First Crusade and the Idea of Crusading (U Pennsylvania Press, 2009). See also the works of Thomas Madden, beginning with his article "Inventing the Crusades," First Things (June/July 2009): http://www.firstthings.com/article/2009/05/ inventing-the-crusades1243195699. See Madden's book The New Concise History of the Crusades (Rowman and Littlefield, 2005); and the collections he edited, Crusades: Medieval Worlds in Conflict (Ashgate, 2010); and The Fourth Crusade: Event, Aftermath, and Perceptions (Ashgate, 2008). For other important studies, see, e.g., Christopher MacEvitt, The Crusades and the Christian World of the East: Rough Tolerance (U. Pennsylvania Press, 2008); and a "popular" presentation that is nonetheless based on solid scholarship: Rodney Stark, God's Battalions: the Case for the Crusades (HarperCollins, 2010).

36 Jonathan Riley-Smiths' The Crusades, Christianity, and Islam, noted above, shows that until the late nineteenth century, almost no Muslim was aware of the Crusades, and those few who were thought them a footnote in history that, if they proved anything, provided evidence of Muslim victory, not victimization! 


\section{DeVille / The Levantine Review Volume 2 Number 1 (Spring 2013)}

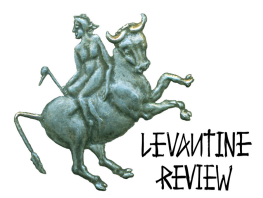

xiii) Historical-Critical Methods Must Be Applied Equally: Academics for more than two centuries have been only too happy to claw away at the Bible in an effort to prove that most of its historical claims, and much else besides, are the products of myth-making from primitive peoples whose silly ideas must be set aside as absurd in our supposedly scientific age. But those same scholars would not dream of applying those same methods to the study of the Quran. Today, however, it seems that we are on the verge of a profound change in how scholars approach the Quran, and in their willingness to ask hard critical and historical questions about the origins of Islam and its sacred texts. In the new works of people like Stephen Shoemaker of the University of Oregon, ${ }^{37}$ and Gabriel Said Reynolds of Notre Dame, ${ }^{38}$ we are, at long last, finding more reputable scholars courageous enough to apply historical-critical methods to the origins of Islam, costly though this may prove to be for them. ${ }^{39}$

37 The Death of a Prophet: The End of Muhammad's Life and the Beginnings of Islam (University of Pennsylvania Press, 2011). I have an extensive interview with Shoemaker about his work on Islam here: http://easternchristianbooks.blogspot.com/2012/08/the-death-of-virgin-andprophet.html.

38 The Emergence of Islam: Classical Traditions in Contemporary Perspective (Fortress Press, 2012).

39 Shoemaker, in my interview with him, noted above (n. 37), had this to say about the costs and dangers of scholarship on Islam today:

But fear of possible reactions from some Muslims today is certainly a factor as well, and here I can speak from my own experience in publishing this book. I originally began with a different publisher. After an almost year-long process of review, we were within a week of having a contract formally authorized. Then I suddenly received an email informing me that some people higher up at the press were only just becoming aware of the book and had concerns that they could not publish any "titles that challenge traditional Islamic orthodoxy" without endangering the staff in their Pakistan office. An additional review was then done by Pakistani scholars of early Islam through the press's Pakistan office. In the end the press - a major English language academic publisher - decided to reject the book solely on the basis, as I was explicitly told, that its contents might upset some in the Islamic world and Pakistan in particular, despite the press's recognition that purely on its scholarly merits the book deserved publication. It was a shocking act of censorship that demonstrates perfectly the difficulties in studying Islam the way that we study other religious traditions. In essence, the press's actions proved my basic thesis: as a general rule we do not study and publish on the history of the early Islamic tradition in the same way that we do for other religious traditions. 


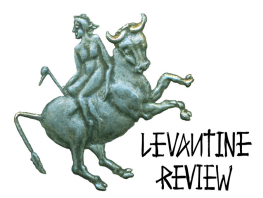

xiv) "Dialogue" Can Be an Academic Fetish: The notion that through "dialogue" one can solve all the conflicts of the Middle East is romantic nonsense as centuries of history have made clear. When it comes to serious believing Muslims and Christians, dialogue can only go so far because both religions ultimately operate out of incommensurate metaphysical systems making irreconcilable truth-claims. While some dialogue may, in a very limited sense, help overcome prejudices or misunderstandings, ${ }^{40}$ or may help ameliorate local conflicts, it will never take away the distinctiveness and singularity of each tradition. ${ }^{41}$

xv) In the Christian East, Everything is Local Custom: One of the hazards, and frustrations, for scholars studying Eastern Christianity is its fragmentary nature and its resistance to any kind of systematizaton. Though it may well be a platitude, it is nonetheless especially true that when studying Eastern Christian realities-and so, I would say, Islamic ones also-one must be acutely aware of the hazards of generalizing, not just between countries, but within the same country or region. Orthodoxy as practiced in Western Ukraine, for example, is considerably different from its practice in Eastern Ukraine, and both regions practice their faith in ways that are different from neighboring Russia, to say nothing of other Orthodox Christians in, say, Serbia, Greece, Syria, or Canada. Even more important, relations between Orthodox Christians in Syria are different from Egypt, which is different from those in Russia, which is different again from those in Lebanon. There is, in other words, a diversity of encounters, past and present, with some being violent and bloodstained while others have been, in certain places and for certain periods at least, far less so. Any serious treatment of the encounters must be cognizant of this great diversity.

\section{CONCLUSION}

In concluding, permit me to underscore that in making bold to articulate these principles, I have done so not from a position of arrogance or from a schoolmaster's desire to boss others around. If I have been presumptuous, I pray your forgiveness. These principles are a plea for sound scholarship because the stakes are too high for too many lives today. If we do not understand the past and present correctly, it will be impossible to build a future that is peaceful. We therefore must have scholarship that eschews politics, including academic politics today, and search only for the

\footnotetext{
40 One good example of this would be Mahmoud Ayoub, A Muslim View Of Christianity: Essays on Dialogue, ed, Mahmoud Ayoub (Orbis, 2007).

${ }^{41}$ An interesting recent survey of Orthodox-Muslim dialogues and perspectives may be found in Andrew M. Sharp, Orthodox Christians and Islam in the Postmodern Age (Brill, 2012).
} 
DeVille / The Levantine Review Volume 2 Number 1 (Spring 2013)

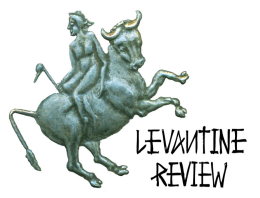

truth, regardless of how inconvenient or incorrect it may be. Only the truth will set us free.

* Adam A.J. DeVille is Associate Professor at the University of Saint Francis, and Editor of Logos: A Journal of Eastern Christian Studies. Dr. DeVille is author, most recently, of Orthodoxy and the Roman Papacy (University of Notre Dame Press, 2011), and editor of the forthcoming Eastern Christian Encounters with Islam (Routledge, 2014) and The Future of Orthodoxy in North America (Notre Dame, 2014.) 